BBACAN 87258

\title{
Hematopoietic stem cell gene replacement therapy
}

\author{
John C. Krauss \\ Internal Medicine, The University of Michigan, Ann Arbor, MI (USA)
}

(Received 7 July 1992)

\section{Contents}

I. Introduction $\ldots \ldots \ldots \ldots \ldots \ldots \ldots \ldots \ldots \ldots \ldots \ldots \ldots \ldots \ldots \ldots \ldots \ldots$

II. Bone marrow transplantation for the treatment of genetic diseases $\ldots \ldots \ldots \ldots \ldots \ldots \ldots \ldots$

III. Murine retroviruses as gene transfer agents $\ldots \ldots \ldots \ldots \ldots \ldots \ldots \ldots \ldots \ldots \ldots \ldots$

IV. Transduction of murine hematopoietic stem cells $\ldots \ldots \ldots \ldots \ldots \ldots \ldots \ldots \ldots \ldots \ldots$

V. Transduction of canine, feline and primate hematopoietic stem cells $\ldots \ldots \ldots \ldots \ldots 2$

VI. Current clinical trials of human gene therapy $\ldots \ldots \ldots \ldots \ldots \ldots \ldots \ldots \ldots$

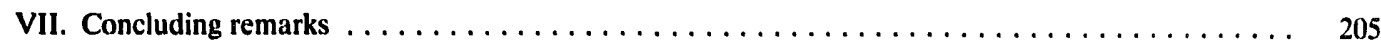

\section{Introduction}

Human gene therapy trials have begun, and by early reports are a success [1]. The initial clinical trial which demonstrated the safety of infusing genetically marked lymphocytes into humans was reported in 1990 [2]. This paved the way for researchers at the National Institutes of Health (NIH) :o begin the first therapeutic trials of treating adenosine deaminase deficient patients with genetically modified lymphocytes. Like the

Correspondence to: J.C. Krauss, Internal Medicine, The University of Michigan, Rm 5510A MSRB I Simpson, 1150 W. Med. Cntr. Dr., Ann Arbor, MI 48109-0680, USA.

Glossary of terms applicable to retrovirus mediated gene transfer: helper virus, wild type retrovirus (usually when referring to a packaging cell line); packaging cell line, cell line that contains the factors in trans to provide for efficient packaging of a retroviral vector. Packaging cell lines have been generated by transfecting parts of the retroviral genome into an appropriate host cell type and seiecting for the generation of viral particles; producer cell line, a packaging cell line that has been transfected with a retroviral vector and selected for production of recombinant retrovirus; recombinant retrovirus, retrovirus that is able to infect cells but lacks the genes necessary for replication; retroviral vector, DNA sequence that encodes for a recombinant retrovirus; transduction, use of a replication incimpetent retrovirus to genetically modify cells; wild type retrovirus, retrovirus that contains a full complement of genes necessary for replication. For murine retroviruses: amphotropic host range, infects a variety of cell types; ecotropic host range, infects only murine cells; xenotropic host range, infects other cell types but not murine cells. initially reported marking study, the ongoing therapeutic trial transduces ex vivo expanded peripheral blood lymphocytes of patients. In both studies the lymphocytes were modified by the addition of genetic material using recombinant retroviruses as the gene transfer substrates. Transduction of peripheral blood lymphocytes is essentially a variation on the theme of genetic modification of the hematopoietic stem cell.

The ability to cure diseases by genetically modifying cells holds great promise. The initial successful human gene therapy trials have rested on a large amount of cell culture modeling and animal experimentation to develop the necessary techniques to genetically modify human cells. The continued successful application of gene therapy will depend on the successful use of gene therapy models leading to carefully designed clinical trials. While a handful of patients have been treated with genetically modified lymphocytes, genetic modification of the hematopoietic stem cell for gene therapy is just now entering the clinical realm, and clinical trials are set to commence in both Italy and the Netherlands [1]. A trial to genetically modify the hematopoietic stem cell of patients in the United States has been approved by the Recombinant DNA advisory committee of the NIH and is awaiting final Food and Drug Administration (FDA) approval [1]. Soon clinical protocols for gene therapy of the hematopoietic stem cell will be taking place on at least two continents.

Gene therapy is essentially a modification of cellular 
therapy. The initial gene therapy protocols have all been very dependent on cellular transplantation techniques. The development of human organ transplantation has recently been reviewed [3]. The ability to remove part of an organ, grow it in short term culture, and implant it into a patient so it correctly functions will greatly enhance the versatility of gene transfer technologies. While transplantation of single cell suspensions has long been possible for bone marrow, this technology has only recentiy been developed for pancreas and liver [4]. Many hurdles are still to be overcome, including the long term and stable expression of the transgene in the engrafted cells and the long term safety of the genetically modified cells. Additionally, issues of both cost and appropriate genetic modifications will become increasingly important as the use of gene transfer technology becomes more widespread.

Somatic gene therapy as presently practiced in humans is the addition of heterologous genetic information into the somatic cells of a patient to treat disease. There are many questions to be answered during the early use of this therapeutic modality. First, what conditions should be considered for gene therapy? As with any developing technology, life-threatening diseases for which no other cure is available make the most attractive diseases to test gene transfer technology. Thus, the first safety trials of genetically modified cells were carried out in patients whose life expectancy was less than $\$ 0$ days due to metastatic melanoma [2]. The first disease to be treated with genetically modified cells (aden ssine deaminase deficiency) was one which curative therapy is only available to those patients with a bone marrow transplantation donor. The currently available palliative treatment of enzyme replacement therapy is extremely costly ( $>\$ 100000 / \mathrm{pt}$-yr) and only marginally effective in one third of the patients [5]. As incrensing knowledge of the technology is being developed, investigators will begin to approach less debilitating and life threatening diseases. The diseases eligible for treatment will need to be carefully defined by the physicians administering the treatment, especially to avoid genetically enhancing individuals rather than treating diseases. Second, what does the future hold? Othe techniques, such as homologous recombination. may offer a significant therapeutic advance over currently practiced gene addition therapy. However, this technology is at least several years from the clinical setting. Additionally, augmentation of cellular function may still prove very important for the treatment of acquired diseases.

The spectrum of genetic diseases that have been amenable to the cellular therapy of bone marrow transplantation should all be theoretically approachable with genetically modified autologous hematopoietic cells. Most of these disorders will still require the cloning of the affected gene. The dieveiopment of complete ge-

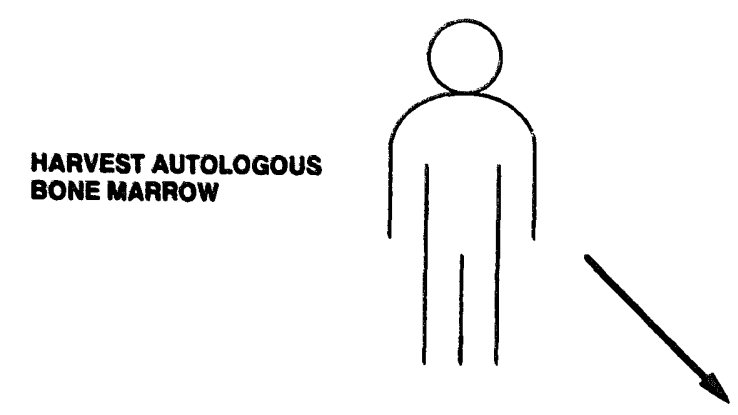

TAANBDUCE CDS4 + CELLS WTTH RECOMBNANT RETAOVIRUS
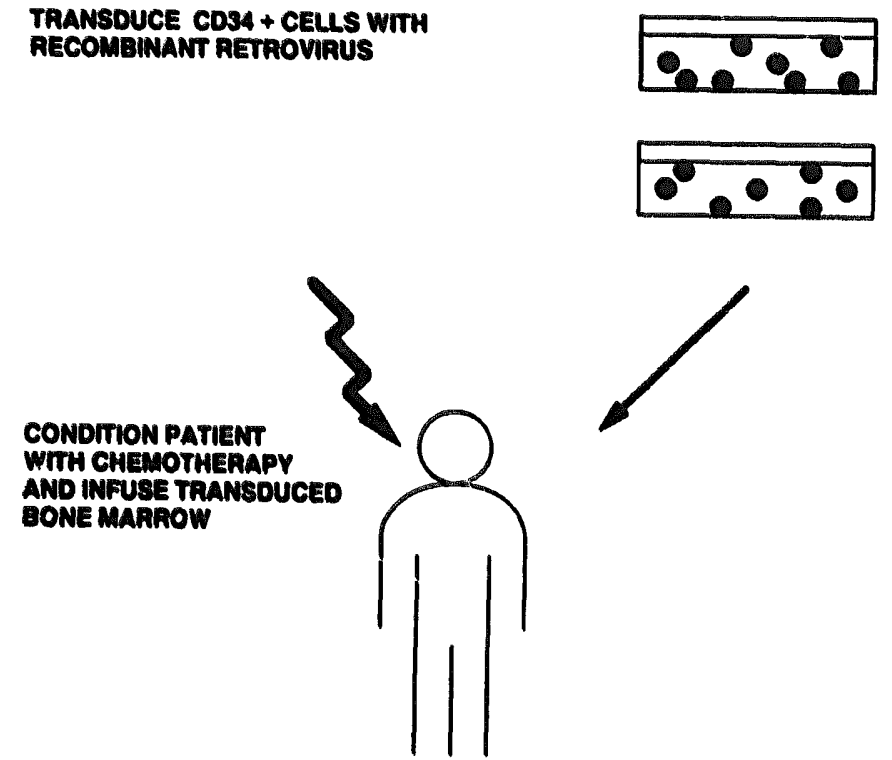

Fig. I. Representation of hematopoietic stem cell gene therapy.

netic maps of the human genome which is underway should facilitate the process of gene therapy. In addition, a variety of acquired diseases should also be treatable with genetically altered cells. For example, it may become routine to genetically alter the peripheral blood stem cells of patients undergoing chemotherapy for malignant disease to ameliorate the hematopoietic toxicity of the chemotherapy [6]. The genetically modified cells could be removed at the completion of the chemotherapy by the incorporation of a suicide gene such as herpes virus thymidine kinase which can be selectively killed in vivo by gancyclovir [7].

Gene therapy has been extensively reviewed [1,8-11]. This review will focus on the use of recombinant retroviruses to genetically alter the hematopoietic stem cell. Most clinical protocols to date have utilized ex vivo gene therapy as outlined in Fig. 1. The ex vivo approach consists of harvesting the target tissue, genetically modifying it, and engrafting it back into the patient. For hematopoietic stem cell gene therapy, the harvest could either be from peripheral blood stem cells obtained through cytophoresis or through autologous bone marrow harvest. The target cell, the multipotent hematopoietic stem cell, can be enriched for by selecting out CD34 positive cells in a single step purifi- 
cation procedure $[12,13]$. The harvested and enriched cells would then be placed in short term culture, prestimulated with growth factors and exposed to the transducing agent. Finally, the genetically modified cells would be infused into the patient, who would be conditioned appropriately with chemotherapy or radiation therapy.

The other major form of gene therapy, in vivo gene therapy, is not yet feasible for the hematopoietic stem cell. This relates to the rarity of the multipotent hematopoietic stem cell in the peripheral blood and bone marrow, and the the problems of specifically delivering gene transfer substrates to those cells. In vivo gene therapy has entered clinical trials for the immunotherapy of melanoma [1]. In the melanoma clinical trial, liposomes containing a complementary DNA (cDNA) for human leukocyte antigen (HLA) B7 will be injected into the metastatic deposits of melanoma cells of patients who do not express the HLA-B7 allele. The first patients are just now being treated with this therapy, and no early results are available. Other target cells which have been proposed for in vivo gene therapy include the arterial wall (endothelial and vascular smooth muscle cells), skeletal and cardiac muscle cells, and hepatocytes [14-16].

\section{Bone marrow transplantation for the treatment of genetic diseases}

Bone marrow transplantation has been extensively studied. Early attempts used bone marrow as a replacement therapy, either by mouth, intramuscular, or intravenously for a variety of disorders of the hematopoietic system [17-20]. The ability to completely repopulate the hematopoietic system with a single cell suspension of bone marrow cells after lethal chemotherapy or radiation therapy has proven therapeutically useful for both genetic disorders and acquired disorders. A large number of lethal diseases are now cured with bone marrow transplantation.

The transplantability of the bone marrow stem cell was defined by investigators studying the effects of radiation toxicity. The original observation was that the 'bone marrow syndrome' of acute radiation toxicity could be alleviated by shielding the spleen from the radiation [20]. This lead to a number of investigators searching for the factors that were produced by the protected spleen that prevented death from acute radiation toxicity. In 1956 it was demonstrated that the protected spleens were providing cells that repopulated the animals and provided for the return of hematopoiesis [21]. In these experiments, lethally irradiated mice and were injected intravenously with a genetically identifiable neonatal spleen cells containing the T6 chromosomal translocation. After recovery of hematopoiesis, the distinctive T6 translocation was isolated from the metaphase preparations of spleen, thymus, and lymph node in the irradiated mice, suggesting the infused cells were engrafting and providing the protective effect against otherwise lethal irradiation. The same authors transplanted mice with the bone marrow of rats, again showing that both lymphoid and myeloid lineages of the animals were being contributed to by the rat cells. These experiments demonstrated that there was multipotent hematopoietic stem cells in both the neonatal spleen (of mice) and the adult bone marrow (of rats) and that these cells could be transplanted and lead to long term, stable re-engraftment. Shortly after this report, the existence of such a cell in humans was transiently demonstrated by the infusion heterologous marrow into patients receiving chemotherapy and radiation therapy for incurable malignancies, and showing the temporary appearance of donor type red blood cells present in the recipients' circulation [22]. These early studies provided the fundamentals which has made bone marrow transplantation a useful therapeutic modality.

It soon became apparent, through both animal and clinical studies, that the major obstacle in transplanting allogeneic marrow was the major histocompatability system $[20,23]$. Grafts across histocompatability barriers result in lethal graft versus host disease. Thus, the use of marrow grafting was limited to lethal conditions among closely HLA matched siblings. Graft versus host disease continues to be a major impediment in the transplantation of marrow among less than perfect HLA matches. Gene therapy hold promise for expanding the clinical utility of bone marrow transplant by genetically modifying the patients' own cells.

Two groups reported curing of a patients with genetic diseases using allogeneic bone marrow transplantation in 1968. The first group reported on a male patient with severe combined immunodeficiency (SCID) who was cured by the transplant of HLA and mixed lymphocyte culture (MLC) identical marrow from his sister [24]. Chromosomal analysis of the recipients bone marrow documented engraftment with $7 / 25$ metaphases being XX. As this patient has SCID, the patient did not require conditioning with chemotherapv or radiation therapy for successful engraftment of his sister's bone marrow. In the same issue of Lancet, another group reported the cure of a boy with Wiskott-Aldrich syndrome. He required conditioning with cyclophosphamide to accept the marrow graft. He engrafted with marrow from his HLA identical sister, as evidenced by $90 \%$ of the metaphases in his marrow having his sister's karyotype (XXX) [25]. Thus, the stage was set for curing genetic disease with allogeneic bone marrow transplantation.

The use of displacement bone marrow transplantation for genetic diseases was reviewed extensively in 1990 [26]. Thirty diseases in which a primary hemato- 
poietic defect is present have been cured with bone marrow transpiantation. For an additional 22 diseases, the transplanted hematopoietic stem cells have been able to supply a soluble factor and significantly lessen the symptoms of the disease. All of these diseases theoretically could be treatable with genetically modified autologous bone marrow, once the respective genes are cloned. Unfortunately, there are five diseases that have not been palliated despite successful engraftment of the hematopoietic stem cell. These are GMl gangliosidosis (acid- $\beta$-galactosidase deficiency), Pompe's disease (acid- $\alpha$-glucosidase deficiency), Nieman Pick type A disease (sphingomyelinase deficiency), Krabbe's disease (galactosylceramidase deficiency), and Farber's lipogranulomatosis (acid ceramidase deficiency) [26]. The failure of bone marrow transplantation to provide therapeutic benefit in Krabbe's disease is particularly discouraging, because bone marrow transplant in an animal model had shown significant improvement in survival [27,28].

A variety of acquired disorders have been cured by bone marrow transplantation [29-31]. They include acute lymphocytic leukemia, acute myelogenous leukemia, chronic myelogenous leukemia, and aplastic anemia. The use of gene transfer technology in these diseases will require selective gene introduction into the malignant cells or normal cells, or other imaginative uses of gene transfer. As this technology is less well developed, the acquired diseases of the hematopoietic system will not be considered further in this review.

The limiting step in hematopoietic gene transfer is efficiency of transferring new genes into hematopoietic stem cells. If culture systems are developed whereby hematopoietic stem cells can be expanded, then less efficient means of gene transfer will become applicable. Gene transfer techniques can be divided into physical methods (for example calcium phosphate transfection), cell fusion or microinjection methods, or vira! methods. As there is not a system yet which can expand hematopoietic stem cells ex vivo, physical and micromanipulation methods are too inefficient. The majority of reports of gene transfer into the hematopoietic stem cell have utilized recombinant retroviruses, which can efficiently integrate up to $1-20$ copies of genetic information into host cells.

\section{Murine retroviruses as gene transfer agents}

The Retroviridae consist of nucleic acid, protein, lipid and carbohydrates [32,34]. A schematic of a retrovirus is shown in Fig. 2. The nucleic acid is a linear positive singie stranded RNA, approximately $1 \%$ of the retrovirus by weight. The genome sediments at $60-70 \mathrm{~S}$, and is composed of two identical subunits, with a tRNA base paired to gcnome complex. The RNA has

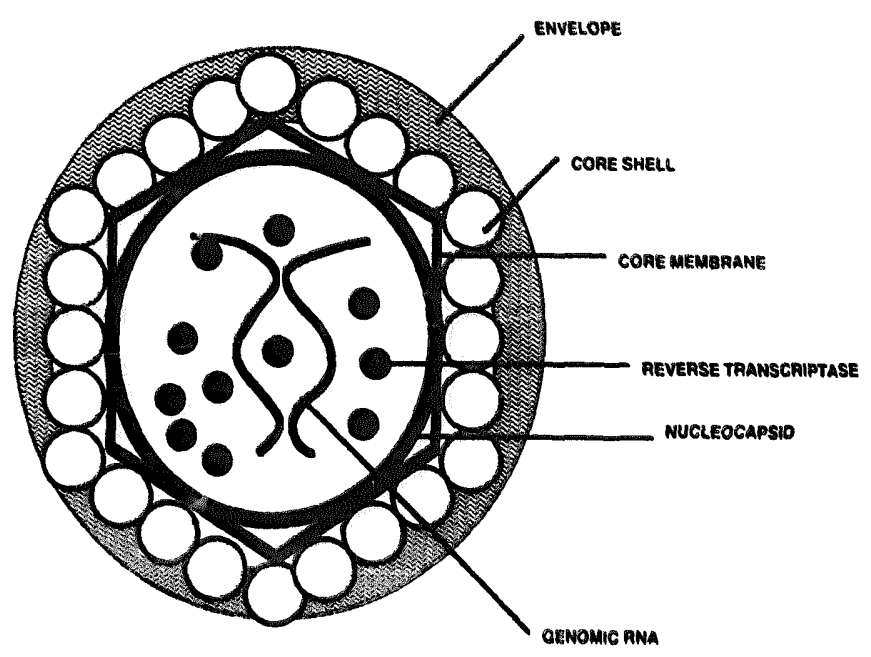

Fig. 2. Morphology of a wild type murine retrovirus.

typical cukayotic modifications of a 5' methyl cap and $3^{\prime}$ poly(A) tail. In a typical wild type virus, only half of the RNA by weight is viral genome, and the remainder is $5 S$ and $7 \mathrm{~S}$ small nuclear RNAs, $18 S$ and $28 S$ ribosomal RNAs, and trace amounts of messenger RNA species. There are also small amounts of host DNA. Moloney murine leukemia virions contain a proline IRNA primer. Retroviruses are about $60 \%$ protein by weight. The proteins are cleavage products of the the three major open reading frames, the group associated antigens (GAG), reverse transcriptase/integrase (POL), and envelope (ENV). Retroviruses are 35\% lipid by weight, all of which is derived from the cell membrane. They are $4 \%$ carbohydrate by weight, and the majority of the carbohydrates are associated with envelope proteins.

Retroviruses have a characteristic morphology which is a spherical enveloped virion (80-100 $\mathrm{nm}$ diameter), with variable surface projections ( $8 \mathrm{~nm}$ diameter). They are grouped into type A, B, C or D, based on their electron microscopic appearance. Moloney virus, which is used for all gene therapy protocols, is a type $C$ virus. Type $C$ viruses have an icosahedral capsid containing a ribonucleoprotein complex with a core shell (nucleoid) in the center of the virus.

The discovery of wild type retroviruses dates back to experiments done by Peyton Rous the early 1900's. He discovered a filterable agent that caused tumors, which is known as the Rous sarcoma virus [34]. Despite intensive efforts, it was not until Ludwig Gross discovered a similar agent in 1951 that could cause leukemia in newborn mice that mammalian retroviruses that caused disease were successfully isolated and passaged [35]. The retrovirus that is used for all clinical trials currently is the Moloney virus, first characterized as a highly leukemagenic virus isolated from sarcoma 37 [36]. The Moloney virus causes $T$ cell leukemia in all injected animals within 6-8 months after injection. 


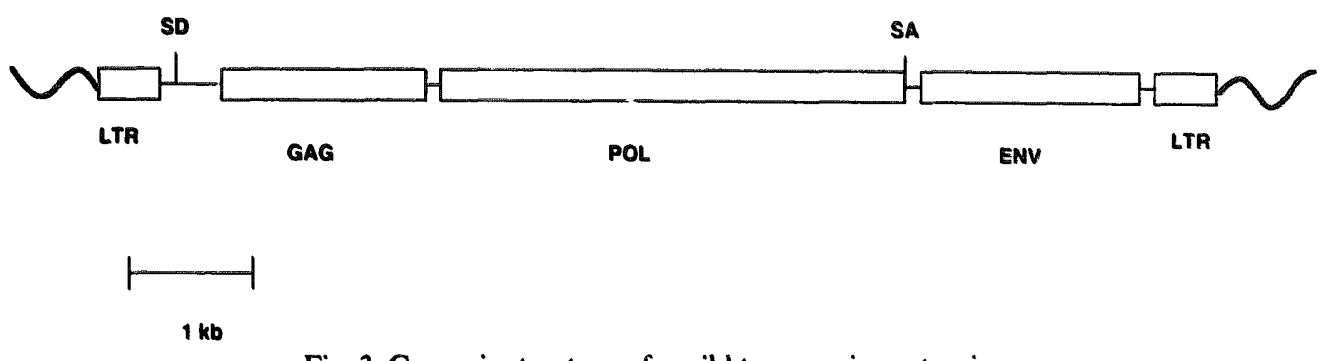

Fig. 3. Genomic structure of a wild type murine retrovirus.

$80 \%$ of the animals have involvement of the thymus, while $20 \%$ have a nonthymic form [37]. The major difference from the Gross virus is its NB tropism, which means it can replicate in NIH Swiss mice (N) and BalbC mice (B). NB tropism is determined by nucleotides in the GAG region, specifically by the $\mathrm{p} 30$ protein [38].

The complete sequence of a noninfectious clone of the Moloney was published in 1981 [39]. Three years later the two nucleotide mutations that rendered it noninfective were discovered and an infectious form was molecularly cloned [40]. This clone was to be used to make the first packaging cells used for human clinical trials, PA317 [41]. The cloning of this virus provided a definitive genomic structure of murine retroviruses, which had been postulated through biochemical and genetic recombination information.

Murine leukemia viruses have a characteristic genomic structure illustrated in Fig. 3 [39]. There are three major genes, GAG (group associated antigen), POL(polymerase; reverse transcriptase and integrase), and ENV (envelope) (reviewed in Refs. 33, 34). Transcriptional regulation is accomplished through the retroviral long terminal repeats (LTR). A standard nomenclature has been developed for the varicus retroviral proteins [42]. Not all proteins are represented in every type of retrovirus.

Each of the structural proteins is translated as a propeptide which is then cleaved into the peptides found in mature virions. The GAG sequence is first translated as a precursor polypeptide of 65 kilodalton (kd) molecular weight. This precursor is then cleaved into the following proteins (listed in N-terminus to C-terminus order as found in the genome) p15(matrix), p12(major phosphoprotein), p30 (capsid), p10 (nucleocapsid), and p14 (proteinase).

The POL gene is translated as a protein of $180 \mathrm{kDa}$ molecular mass, consisting of a fusion protein of the GAG and POL genes. in infected cells, there is a $1: 10-1: 100$ ratio of the $180 \mathrm{kDa}$ GAG/POL protein to the $65 \mathrm{kDa}$ GAG protein. Translation of $\operatorname{Pr}_{|\times|}$ GAGPOL probably occurs by reading through an amber stop codon at the end of the GAG sequences. Approximately one half of the POL protein is directly responsible for the reverse transcriptase function, while the other half of the molecule functions as an inte-

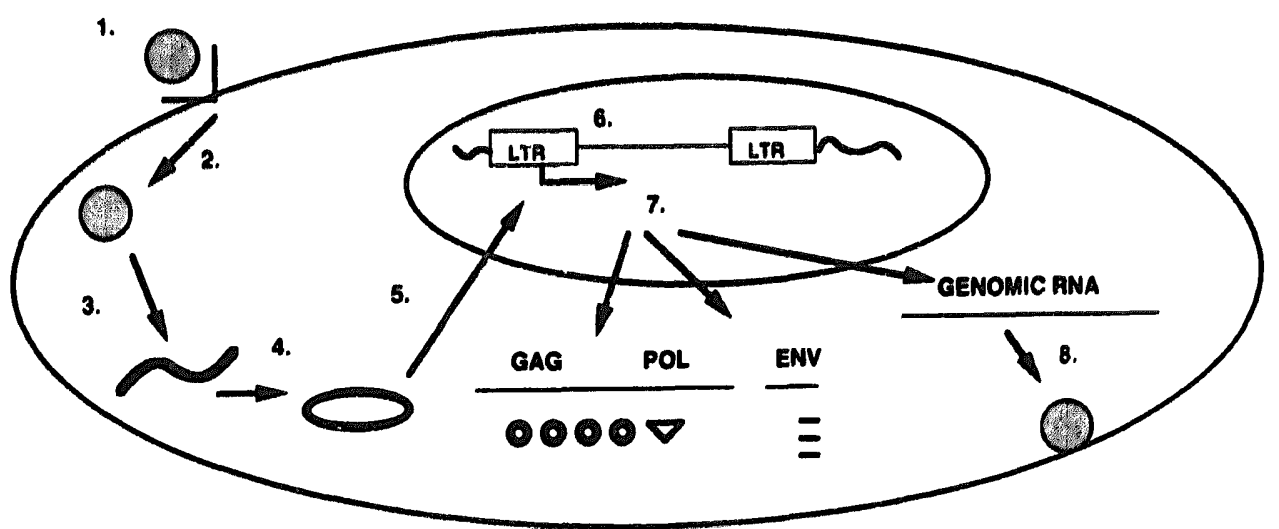

9.

Fig. 4. Wild type retrovirus life cycle. (1) Attachment of the retrovirus to a specific receptor through interactions with its the retroviral etivelope proteins; (2) internalization of the retrovirus; (3) disruption of viral RNA and reverse transcriptase/integrase complex into the cytoplasm; (4) reverse transcription of single stranded (ss)RNA to sSDNA, and then second strand DNA synthesis to form a double stranded circular intermediate; (5) transportation of the double stranded DNA to the nucleus; (6) integration of proviral DNA into the host cells genomic DNA at sites without apparent sequence homology; (7) transcription of the provirus; splicing to subgenomic and genomic RNA forms; (8) assemble of the retrovirus at the cell membrane; (9) budding of the retrovirus from the cell. 
grase. There are $20-70$ copies of POL per virion, and at least one molecule of POL is tightly associated with the genomic RNA.

The final gene is envelope (ENV). Envelope is translated from a spliced messenger RNA as a precursor of $80 \mathrm{kDa}$ molecular mass. This precursor protein is then cleaved into gp70 and gp15. Gp70 is the major envelope structural protein. Among different retroviral isolates it is highly polymorphic. This protein determines the host range of the retrovirus. p15E functions as the $\mathrm{gp} 70$ anchor and is also known as the transmembrane protein.

The long terminal repeats are critical for replication. integration, and transcriptional functions of the retrovirus. Their genomic structure has been exhaustively studied. The long terminal repeats are divided into three structural regions known as US, R and U3. The orientation of these elements is the same in the 5' and $\mathbf{3}^{\prime}$ long terminal repeats. The $\mathrm{U} 3$ region provides for most of the transcriptional control. It contains a negative acting upstream control region, a enhancer region that is duplicated, and a TATA box for the initiation of transcription. The $R$ region contains the consensus sequence for polyadenylation. It also is important in the transfer of chain synthesis during retrovirus replication. The U5 region contains the IRNA primer binding site used for initial negative strand DNA synthesis.

The assembly of retroviral particles is a complex process that is not yet fully elucidated. As shown through electron microscopic studies, it appears that the assembly of type $\mathrm{C}$ retroviral particles occurs at the plasma membrane. Some protein processing also oc. curs in the budded retroviral particle, as newly re. leased virions are less infectious than older virions.

The normal retrovirus life cycle is depicted in Fig. 4. The following discrete events can be identified. The specific events in retrovirus infection and replication are attachment to the receptor, internalization of the retrovirus, synthesis of double stranded DNA in the cytoplasm through reverse transcription, transport to the nucleus, integration of the DNA into sites without apparent sequence homology, production of subgenomic and genomic RNA transcripts, and assembly of the virus and budding of the mature virions. For use in gene therapy, retroviruses have been genetically modified to provide for efficient gene transfer without causing the spread of wild type virus in the host animal. The modification is to render them replicatiun defec. tive by removing part of $G A G$, and all of the POL and ENV genes. DNA sequences of interest are then cloned into the proviral genome. The replication defective vectors are passaged by the use of packaging cell lines, which are described in th: following text. $A$ glossary of terms that are frequently used is provided at the beginning of the text.
The earliest use of retroviruses as shuttle vectors was in transferring the thymidine kinase gene from herpes virus [43,44]. In 1983 investigators used a molecular hybrid of the Moloney sarcoma virus and the Moloney leukemia virus in combination with replication competent retrovirus to complement the defect in hypoxanthine phosphoribosyltransferase (HPRT) deficient cells lines (mutant HELA cells, SV-40 transformed fibroblasts, and EBV-transformed lymphoblasts) [45]. In 1984 the same group was able to express human HPRT in the bone marrow of mice using a mixture of wild type retrovirus and the recombinant HPRT encoding retrovirus [46]. The mice remained viremic, and so it was impossible to conclude whether or not the hematopoietic stem cell had been transduced with the recombinant retrovirus, or whether early hematopoietic progenitors were persistently reinfected, leading to continued transgene expression.

The key to bringing retrovirus mediated gene transfer into the clinical arena was the development of packaging cell lines that could produce high titers of replication defecive recombinant retrovirus. The development of packaging cell lines depended on several important observations. First was the identification of the packaging sequence of an avian retrovirus (the spleen necrosis virus). In 1982 the sequences between nucleotides 100 and 285 from the 5' long terminal repeat (LTR) were identified as necessary for the recovery of infectious virus [47]. In 1983 this observation was extended to the murine retroviruses, and a murine retrovirus packaging cell line was created [48]. Deletion of similar sequences as described for the avian retrovirus from a Moloney murine retrovirus (a 531 bp $B a l$ I-Pst I fragment) reduced packaging of the mutant genome by at least 100-fold as compared to the wild type genome. The mutant genome was stably transfected into NIH3T3 cells, creating the packaging cell line known as $\Psi_{2}$. The packaging cell line $\Psi_{2}$ was able to package a shuttle vector which encoded for a bacterial drug resistance gene efficiently in the absence of detectable levels of wild typs virus. Virus produced by $\Psi_{2}$ cells is between $10^{5}-10^{6}$ colony forming units (CFU)/ml.

Because they encode for a native Moloney ecotropic envelope protein $\Psi_{2}$ cells are only able to infect murine cells. An amphotropic packaging cell line called $\Psi$ am was reported by these same investigators in 1984 [49]. The amphotropic packaging cell line was made by switching the native ecotropic Moloney cnvelope proviral sequence to an amphotropic envelope proviral sequence derived from the virus $4070 \mathrm{~A}$. Using this packaging cell line amphotropic retroviral stocks with titers of $10^{4}-10^{5} \mathrm{CFU} / \mathrm{ml}$ were generated. This virus has titers on human HELA cells as high as murine NIH3T3 cells, and showed good levels of retrovirus derived transcription. However, quantification of retrovirus de- 
rived protein levels were not made. The successful development of an amphotropic packaging cell line based just on the envelope sequences of $4070 \mathrm{~A}$ was in distinct contrast to another group's attempt to make a packaging cell line derived all from cloned fragments of the $4070 \mathrm{~A}$ virus. The $4070 \mathrm{~A}$ alone derived packaging cell line has almost 100 -fold lower titer than $\Psi$ am [50]. Although amphotropic cell lines are able to infect a wide variety of cell types, they are unable to infect Chinese hamster ovary $(\mathrm{CHO})$ cells.

Like $\Psi_{2}$ cells, the $\Psi$ am cell line occasionally developed helper virus on prolonged passage, or after transfection with certain types of retroviral vectors. Both the $\Psi_{2}$ and $\Psi$ am represented first generation packaging cell lines. Probably because the packaging sequence deletion does not completely ablate packaging of the mutant genome, there is occasional formation of wild type virus with these cell lines. This probably occurs through the occasional copackaging of the mutant genomes witl the vector genome, and subsequent recombination between the two genomes leading to wild type virus formation.

In 1986, a second generation of packaging cell lines was described called PA317 [41]. These packaging cell lines had several modifications to reduce the likelihood of recombinational events that could lead to wild type virus formation. The plasmids used to generate these lines were derivatives of the originally sequenced Moloney virus which had been corrected at two base pairs to become infectious [40,51]. As with the original packaging ccll lines, the packaging sequences were removed from the parental proviral DNA sequences. Another modification was the removal of the $3^{\prime}$ long terminal repeat and replacement with an SV40 polyadenvlation signal. Stable transfectants of NIH3T3 cells with this plasmid construct were screened for their packaging ability. The best clone (PA317), is able to package an $\mathrm{N} 2$ based provirus which encodes for a mutant dihydrofolate reductase (DHFR) with titers up to $10^{7} \mathrm{CFU} / \mathrm{ml}$ without helper virus formation. The FDA of the United States has approved PA.317 for use in several different clinical trials involving human gene therapy [1].

To further reduce the risk of helper virus formation, two different sets of third generation packaging cell lines were developed. The first described were $\Psi$ cre and $\Psi$ crip [52]. They separate the retroviral genome into two separate parts, to further reduce the chances of recombinational events leading to wild type virus. These changes increase the number of recombinational events necessary for wild type virus formation from two with PA317 to three. The $\Psi$ cre and $\Psi$ crip packaging cell lines were made from a total of three plasmids, with two plasmids for each cell line. All three of the plasmids have an SV40 polyadenylation signal in place of the $3^{\prime}$ long terminal repeat. The plasmid that pro- vides the GAG and POL proteins is common to both celi lines. It is referred to as pcrip-env and it has a mutant R21 envelope gene. The $\Psi$ cre cell line (which produces ecotropic virus) contains pA5 mutant GAG/POL genes and the native Moloney envelope sequences, and the $\psi$ crip cell line (which produces amphotropic virus) contains the pA5 mutant GAG/ POL genes and the 4070A envelope gene. Both of these cell line were constructed in a similar manner. First the normal GAG/POL plasmid was transfected into NIH3T3 cells, and the clones were screened for reverse transcriptase production. The cell lines that produced the most reverse transcriptase activity were transfected with the respective ENV plasmids and the clones were screened for packaging function. Titers of these two packaging cell lines are in the range of $1 \cdot 10^{6}$ $\mathrm{CFU} / \mathrm{ml}$, with a parallel $\psi_{2}$ titer $2 \cdot 10^{\prime \prime} \mathrm{CFU} / \mathrm{ml}$. Of note, the $\psi /$ crip cell line was recently approved for use in a human clinical trial for the genetic modification for hepatocytes in patients with familial hypercholes. terolemia [1].

The other third generation packaging cell line producers are known as GP + E86 (an ecotropic packaging cell line) and GP + envam 12 (an amphotropic packaging cell line [53,54]. These packaging cell lines have the major advantage that the GAG/POL proviral information was put on the same plasmid as a dominant selectable marker, and thus selection in hypoxanthine, mycolphenolic acid, and xanthine are able to rescue GAG/POL function from populations of packaging cells that have lost their packaging function. These investigators utilized Moloney virus clone 3PO. These packaging cells lines have been reported to package N2 at a titer of $4 \cdot 10^{\mathrm{h}} \mathrm{CFU} / \mathrm{ml}$.

The development of vectors has been closely tied to the development of packaging cell lines, and also to the specific experimental aims of the investigators. The ideal gene therapy retroviral vector is safe (does not lead to helper virus formation), provides high titer virus (greater than $10^{5} \mathrm{CFU} / \mathrm{ml}$ ), and provides for high level protein expression in the transduced cell population. The safety issue is a relative one. The FDA has developed guidelines for recombinant retroviruses for gene therapy that have been published $[55,56]$. Safety from a clinical point of view relates to the minimization of chance of exposure to helper virus. For clinical virus stocks, this has meant that no replication competent virus can be present in the stocks as measured by provirus mobilization assays. In addition. the retrovirus stocks also need to be free of other potential human pathogens as is required of other all other drug products.

Retrovirus titer is not only related to the specific packaging cell line used, but also to the retroviral vector that is being packaged, and to the method used to generate the producer cell. A schematic of four 

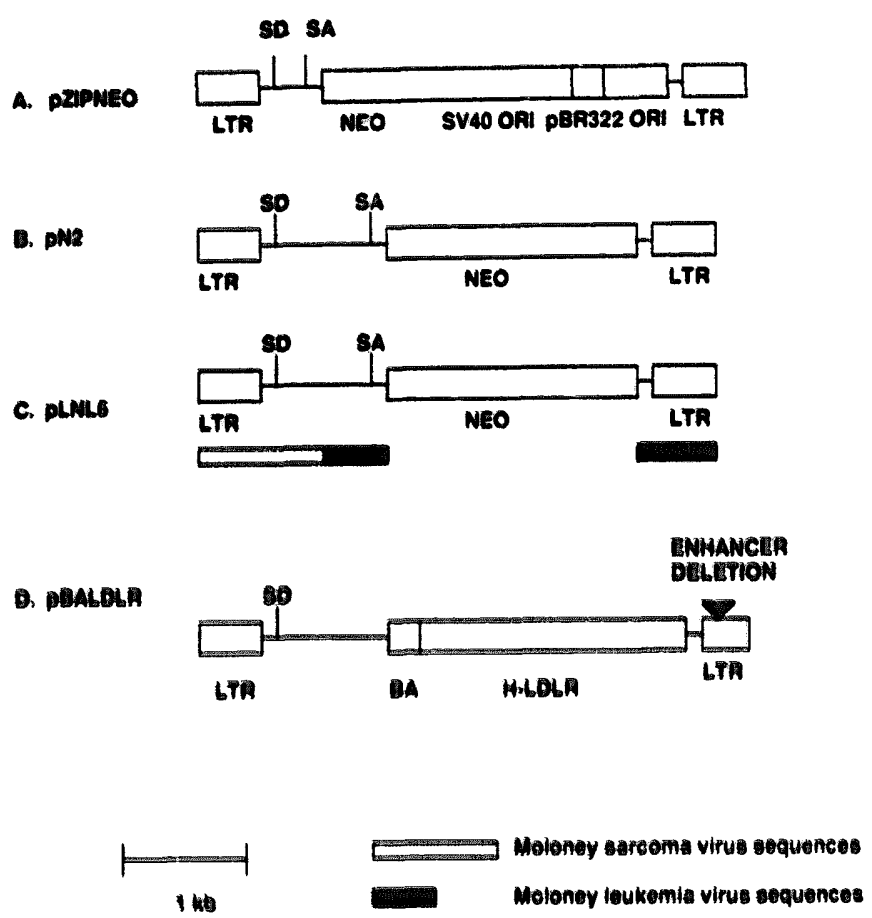

Fig, 5, Genomic structure of four retroviral vectors: A. pZipneo; B, pN3: C. PLNLG; D. pBALDLR.

different types of retroviral vectors is shown in Fig. 5 . Early vectors were essentially modifications of replication incompetent acutely transforming viruses, with the gene of interest placed about $600-800$ base pairs (bp) after the 5' end of the proviral sequence. The first generation of vectors produced without helper virus are typified by pZip [57]. This vector included just $\mathbf{5 5 6}$ bp of the ' 5 flanking region. This vector aiso has sequences for expression in COS cells (an SV40 origin) and for cloning the genome from transduced cells (a pBR322 origin). The cDNA was most efficiently expressed from the LTR as compared to the SV40 internal promoter. Using this retroviral vector and $\boldsymbol{\Psi}_{2}$ cells, titers of $10^{\circ} \mathrm{CFU} / \mathrm{ml}$ could be generated.

The second generation of vectors is typified by $\mathrm{N} 2$. which included more GAG sequences, $a_{i} !$ also included the endogenous $3^{\prime}$ splice site [58]. With this vector titers of $10^{7} \mathrm{CFU} / \mathrm{ml}$ could be generated, but helper virus formation was observed when used with the first generation $(\Psi, \Psi$ am) cell lines. A critical observation was that the extended GAG sequence in the vector provided for increased packaging of the genomic proviral RNA and provided for increased titer [59]. Specifically, it was demonstrated that inclusion of a portion of GAG increases the titer of the retrovirus by 10-100-fold (Moloney murine leukemia virus bases 566-1038). Also heterologous RNAs were able to be efficiently packaged into retroviral particles when bases 215-1019 were attached to the RNAs, even in the absence of the remainder of the retroviral sequences [60].
The first retroviral vectors used in clinical trials is the third generation LNL6 vectors $[59,61]$. This is a hybrid vector with a $5^{\prime}$ Moloney sarcoma virus genome and a $3^{\prime}$ Moloney leukemia virus genome. It has been further safety modified by site specifically mutating the normal GAG start codon from an ATG to a TAG, which in several assays leads to lower wild type virus formation.

The other vector type that was recently approved for clinical trials in familial hypercholesterolemia is an enhancer deleted vector. This vector has one of the $3^{\prime}$ LTR internal enhancers (7933 Pvull to $8111 \mathrm{Xbal}$ ) removed, which greatly decreases LTR transcription in transduced cells, but still produces relatively high virus titer. Use of this vector with an internal chicken $\beta$-actin promoter has been able to achieve a large amount of protein expression in a variety of different cell types $[62,63]$.

A new class of vectors that appears interesting are the polycistronic vectors, which utilize sequences from picornaviruses to achieve more efficient translation of both sequences in a bicistronic messenger RNA [64]. Earlier vectors (i.e., pZIPNEO) rely on retrovirus RNA splicing in the transduced cells to achieve efficient RNA translation. The polycistronic vectors utilize the $5^{\prime}$ untranslated region of encephelaomyocarditis virus (EMCV) to achieve more efficient translation of a bicistronic RNA. One of these vectors is able to produce two times the NPT activity from a downstream location as compared to an SV40 vector. Viruses produced with these vectors are of high enough titer to potentially be useful as clinical gene transfer agents.

Retroviral titer is very important for hematopoietic stem cell gene transfer. Retroviruses with titer of less than $10^{5} \mathrm{CFU} / \mathrm{ml}$ are of very low efficiency in transducing the hematopoietic stem cell. The method of production of the producer cell line also probably influences retrovirus titer. Typically a producer cell line is made by transfecting the retroviral vector into the packaging cell line, performing selection, and screening clones of the selected cells for the production of virus. Physical means such as calcium phosphate precipitation and electroporation will give reasonable titer retrovirus by this method, although only $10 \%$ of the clones screened will produce retrovirus. For vectors that do not contain an enhancer deletion, a way of increasing the number of virus producing clones is to infect a packaging cell line with virus made from a packaging cell line of different host range [66]. For clinically useful gene therapy stocks, this entails producing virus from the ecotropic packaging cell line and using it to cross infect the amphotropic packaging cell line. Using this method, most of the screened clones will be positive for the production of retrovirus. In addition, higher titer virus may be produced more relıably. Repetitive cross infection may provide for up 
to a 10-fold higher titer virus [66]. Some of the highest titer virus stocks that have been reported use cocultivation of ecotropic and amphotropic stocks to repetitively cross infect the opposite cell type [65]. This type of maneuver, however, almost always results in helper virus formation in the available packaging cell lines. Even in cell lines with no homology to the retroviral vector being passaged, repetitive cross infection has lead to helper virus formation [67]. Thus, other strategies may need to be developed to generate retrovirus stocks of high enough titer to reliably infect hematopoietic cells of primates.

\section{IV. 'Transduction of murine hematopoietic stem cells}

The first insertion of genes into the hematopoietic stem cells did not utilize retroviruses but rather traditional calcium phosphate transfection and selection for the introduced gene [68]. These experiments were pub. lished in 1980. Marrow was harvested from T6T6 mice that had been pretreated with vinblastine to increase the number of cycling hematopoietic stem cells. The genetically identifiable marrow was transfected with total cellular DNA from a mouse cell line resistant to methotrexate. The transfected cells were mixed with an equal number of normal bone marrow cells that were transfected with normal DNA, and the cell mixture was then transfused into lethally irradiated recipient mice. The mice were treated with methotrexate during the time that they re-initiated hematopoiesis. The investigators demonstrated an excess of the methotrexate resistant treated cells (the T6T6 cells) in marrow of mice treated with methotrexate. In addition, they were able to protect from toxicity of methotrexate in mice that received the transfected bone marrow. They performed additional experiments to prove that the hematopoietic stem cell had been transfected. They transplanted 'secondary' mice with the bone marrow from their primary recipient mice. The secondary mice had a higher percentage of the transfected (T6T6) marrow type. The same investigators were able to show an increase in dihydrofolate reductase (DHFR) activity in the spleens of the transplanted animals. These experiments opened the door for hematopoietic stem cell gene therapy. Using a similar approach, in 1981 the same group was able to demonstrate thymidine kinase sequences in the marrow of mice [69]. The major limitations the calcium phosphate transfection technique are the inefficiency of gene transfer and the lack of stability of the introduced sequences in the absence of ongoing drug selection.

While replication competent retroviruses had been used to express the HPRT gene in mice, the first use of a replication incompetent virus to genetically alter bone marrow was in 1984 [46,70]. The major advance of using retroviruses as the gene transfer substrate was the several order oi magnitude increased rate of gene transfer into murine bone marrow cells. These investigators were able to obtain transfer of provirus into $10-25 \%$ of colony forming unit spleens (a primitive hematopoietic progenitor), at between $0.1-0.25$ proviral copies per cell. This rate of gene transfer was observed with both short term cultivations and long term (Dexter) culture conditions. Positive spleen colonies (which are clonal in nature) showed multiple sites of proviral integration, suggesting that it was possibie to achieve a potentially therapeutic gene dosage level. While these experiments did demonstrate adequate provirus levels, transcription of the provirus was not demonstrated, nor was provirus derived protein in the tissues of the transplanted animals. Addi tionally, assays for provirus in long term ( $>4$ months) animals were not performed, and provirus levels before this time may only reflect early hematopoietic progenitor infection.

The first experiments that conclusively demonstrated expression of the transgene after helper virus free retrovirus gene transfer were published in 1985 [71]. Using 5-fluorouracil treated marrow transduced with an N2 retrovirus that encoded for neomycin resistance,neomycin phosphotransferase (NPT) activity was demonstrated in the bone marrow of the transplanted mice. In addition, a common integration pattern of the provirus in all tissues derived from the hematopoietic stcm cell was shown, suggesting that only a limited number (1-5) hematopoietic stem cells were contributing to hematopoiesis. 'They also formed $T$ cell and $B$ cell hybridomas from the cells of selected transplanted mice to investigate whether any provirus could be detected that was not contributing to hematopoiesis. By Southern Blot, both the B cell and $T$ cell hybridomas contained the major proviral integrants observed in the tissues of the mice, and a few other integrants. This suggests that not all hematopoietic stem cells are contributing to lymphopoiesis at any one time. These experiments represented a major advance in hematopoietic stem cell gene therapy. However, neomycin activity is only a reporter enzyme in this context, and it is impossible to determine if therapeutically relevent quantities of the recombinant protein were being generated in the transduced bone marrow.

In 1990, the consistent expression of human adenosine deaminase in mice was achieved with amphotropic retroviruses, paving the way for these investigators to submit a clinical protocol to transduce the hematopoietic stem cell of patients with ADA deficiency [72]. In these experiments, human ADA was expressed in mice transplanted with bone marrow transduced with amphotropic retroviruses. The vector used for these experiments contains a mutat LTR, which is designed to increase protein expression in the cells derived from the transduced hematopoietic stem cell. At 34 days, 
10/10 mice were positive for human ADA activity. In this same series of experiments a secondary transplant recipient had expression of h-ADA derived from proviral sequences. The major limitation of these experiments was that they were only able to show expression in $40 \%$ of peripheral blood lymphocytes and $20 \%$ of thymocytes. In addition, no data was presented on the long term protein expiession in the transplanted mice.

A variety of other genes have been expressed in the hematopoietic stem cells of mice using retrovirus mediated gene transfer [73-77]. Most of these are to model a specific disease. One model is of note because of the ability to study cell specific expression in transplanted mice. In 1991 investigators reported on an animal model of CD18 gene replacement therapy [78]. Leukocyte adhesion deficiency is a rare disease caused by a defective CD18 gene. These experiments utilized an ecotropic retrovirus, to express human CD18 for greater than 4 months in $40 \%$ of a cohort of transplanted mice. Cell specific expression of human CD18 was determined in the mice by using monoclonal antibodies directed at both mysloid and lymphoid epitopes demonstrating a restriction of transgene expression in lymphoid cells. The restricted lymphoid expression is on the basis of decreased transcription of the provirus in the lymphoid tissues [79]. This type of model is of particular use because the cell specific expression of the transgene can be exhaustively studied.

The expression of foreign sequences in the mouse has proven to be a powerful model for human gene therapy trials. Several hurdles remain to be overcome concerning hematopoietic stem cell gene transfer, and the murine model should provide a powerful tool to perform these experiments. The major limitation in all experiments to date has been transfer of the genetic information into all of the hematopoietic stem cells that will eventually contribute to hematopoiesis in a lethally irradiated animal. Two approaches are currently being investigated to overcome this problem. The first approach is to better understand the biology of the hematopoietic stem cell to effert reliable division of such cells in short term culture. The hematopoietic stem cell of mice was first isolated in 1988, but there have been some subsets identified since that time [80,81]. However, specific protein growth factors that reliably lead to an increase in the number of such cells have not yet been identified [82]. The development of assays for primitive hematopoietic stem cells short of repopulation of lethally irradiated animals may lead to the identification of such protein growth factors. Such work is underway in a number of laboratories. Another approach is to increase the mutiplicity of infection with the retroviral particles. This can either be through the partial or complete purification of the hematopoietic stem cell, or through increasing the titer of the retrovirus $[83,84]$ (and below). Both approaches are being actively pursued. A final problem that can be addressed with the murine inodel is the cell specific expression of the transgene in the variety of cells that arise from transduced hematopoietic cells. Strategies that increase expression such as altering the promoter of the provirus are being actively studied. Thus, the murine hematopoietic gene therapy model still has much to offer, even as clinical trials are beginning for human hematopoietic gene therapy. In addition, the ability to generate knockout mice by homologous recombination may provide for a number of murine animal models of human diseases.

\section{Transduction of canine, feline and primate hemato- poietic stem cells}

Hematopoietic stem cell gene therapy has been attempted on larger animals to test the concepts originally pioneered in mice. The most extensive experience has been with the transduction of canine hematopoietic stem cell. Dogs offer a particularly useful model as they are an outbred species and several groups have extensive bone marrow transplant experience with dogs [87]. In addition there is a proven ability to cure genetic diseases by performing displacement bone marrow transplantation in dogs $[86,87]$.

In 1988 the first experience with transferring genes into the hematopoietic stem cell of dogs was reported [88]. Six dogs were transplanted with bone marrow transduced with two different retroviruses. One virus encoded for neomycin resistance and had a titer of $2 \cdot 10^{\mathrm{h}} \mathrm{CFU} / \mathrm{ml}$, but was contaminated with greater than $10^{3}$ helper virus [89]. The other virus encoded for a mutant dihydrofolate reductase (DHFR), had a titer of $3 \cdot 10^{\text {h }} \mathrm{CFU} / \mathrm{ml}$, and was helper virus free [89]. In addition, an attempt was made to select for transduced cells prior to transplant by culturing (preselecting) the transduced bone marrow in drug containing media. Six dogs were transplanted with transduced bone marrow and $4 / 6$ survived the procedure. Only $1 / 3$ dogs transplanted with preselected bone marrow cells survived, while all 3 dogs transplanted with unselected bone marrow cells survived. Provirus could not be detected by Southern blot in any of the animals, so less than $2-3 \%$ of the hematopoietic progenitors were transduced. Between 2-5\% of the hematopoietic progenitors were resistant to methotrexate, and the resistant percentage could be increased slightly with methotrexate treatment of the transplanted dogs. Thus, only low level gene transfer into the hematopoietic stem cell was occurring with these dogs.

In 1992 another group reported their experience with genetically marking the hematopoietic stem cells of dogs [90]. Dogs were transplanted with bone marrow transduced with helper virus free $\mathrm{N} 2$ (neo) virus with a titer of $10^{6} \mathrm{CFU} / \mathrm{ml}$. The animals were extensively 
tested and all remained helper virus free for the duration of the experiment. In order to increase gene transfer efficiency, the marrow was placed into long term cultures and transduced with retrovirus 1-3 times over a 21 day period. With this regimen up to $85 \%$ of hematopoietic progenitors from the long term cultures became drug resistant, suggesting a high level of gene transfer into this cell type. Four dogs were transplanted with marrow conditioning (myeloablative radiation) and 3 of the 4 dogs survived. In addition, 3 dogs were transplanted without marrow conditioning and all survived. There was no difference in gene transfer rates between the two groups of dogs. Gene transfer was assessed by growing hematopoietic progenitors in drug selection and then testing the resistant progenitors for the presence of proviral sequences by the polymerase chain reaction. Proviral sequences could be demonstrated in no more than $10 \%$ of the hematopoietic progenitors at time points of up to one year. Additionally, $0.1-1 \%$ of $\mathrm{T}$ cells were genetically marked. Two conclusions can be drawn. First, the $85 \%$ rate of gene transfer into hematopoietic progenitors was not reflective of the hematopoietic stem cell transduction rate. Second, only low levels of gene transfer was achieved into the canine hematopoietic stem cell. Thus, more efficient protocols for canine hematopoietic stem cell transduction should be developed.

In 1992, another group reported their experience with genetically modifying the hematopoietic stem cell of cats [91]. The retrovirus used was a variant of the N2 virus and was helper virus contaminated. Four cats were transplanted with transduced bone marrow and all four survived the bone marrow transplant. Up to $7 \%$ of the hematopoietic progenitor colonies were neomycin resistant between 1 and 35 months after transplantation. Proviral sequences in tissues of transplanted animals could not be detected with Southern blot, so probably less than $5-10 \%$ of the cells were genetically modified. They were able to detect proviral sequences with the polymerase chain reaction in the drug resistant hematopoietic progenitor colonies. NPT activity was demonstrated in cells derived from one animal. None of the cats were viremic with Moloney virus, but evidence of helper virus genome was detected in $2 / 3$ animals tested. Two animals developed diabetes with an atypical pancreas histology, but this could not be directly related to the presence of the replication competent virus.

Thus, the published experience with gene transfer into cats and dogs consistently demonstrates less than $10 \%$ of the hematopoietic stem cells that repopulate an animal can be reliably transduced. The same factors that prove important for gene transfer in the mouse will probably prove to be important in dog and cat hematopoietic stem cell gene transfer. These animals will provide utility in developing clinical protocols be- cause several authentic animals models exist of human diseases in both dogs and cats.

Gene transfer has been achieved in the hematopoietic stem cells of primates as well. The initial experience with primate gene transfer was reported in 1987 and updated in 1990 [66,92-94]. The initial successfu! report of expressing human adenosine deaminase in the hematopoietic cells of primates was reported in 1987 [92]. Investigators reported on the bone marrow transplantation of 6 cynomologous macque (Macaca fasicularis) monkeys with bone marrow transduced with the SAX vector. This virus expresses both human adenosine deaminase and NPT and has a titer of $6 \cdot 10^{6} \mathrm{CFU} / \mathrm{ml}$. Two methods of transduction of the bone marrow were performed. One was cocultivation of the bone marrow cells with the retrovirus producer cells and the other was transduction with retrovirus supernatants. With cocultivation, NPT activity and adenosine deaminase (ADA) activities (ADA less than $0.01 \%$ of endogenous) were detected in cells derived from the bone marrow. In one animal, investigators detected a provirus band at day 66 (of about $1 / 3$ copy). With the supernatant infection protocol provirus sequences were undetectable by Southern blot. By in situ hybridization, $0.8 \%$ of the peripheral blood cells contained vector specific mRNA sequences. Up to $2 \%$ of hematopoietic progenitors were drug resistant, and up to $8 \%$ of clonable $\mathrm{T}$ cells were drug resistant. These experiments were limited by the fact that they did not have access to some of the more recently cloned hematopoietic growth factors.

An update of this work was reported in 1989 [93]. At that time a total of 14 monkeys had been iransplanted with transduced bone marrow, 10/14 which survived the transplant procedure. Six of fourteen animals were positive for human ADA activity, at best $0.5 \%$ of endogenous monkey ADA activity, and none of the animals demonstrated long term expression of human ADA activity. Only 1/14 animals was positive for provirus derived DNA sequences, and that animal was only positive at a single time point. Four of fourteen monkeys were positive for NPT activity, and none were persistently positive for NPT activity. In 1990 another summary of this data was reported, stating that of a total of 20 monkey transplanted, $2 / 20$ monkeys expressed human ADA at $\mathbf{0 . 2 - 0 . 5 \%}$ of endogenous ADA activity, and no human ADA activity was detected past 90 days [65].

In 1990, another group reported their experience with transplantation of rhesus monkeys (Macaca mulatta) with bone marrow transduced with neomycin encoding retrovirus [65]. The report describes the transplantation of 6 monkeys, all of whom survived. Three monkeys were transplanted with marrow transduced with a conventional titer virus, but that had been additionally modified to secrete interleukin 3 and inter- 
leukin 6 into the tissue culture media. This retrovirus was helper virus free. None of the three monkeys transplanted with this marrow were positive for proviral DNA, despite the use of a sensitive polymerase chain reaction method to detect proviral sequences. Thus, despite many attempts, only low level or no gene transfer into the hematopoietic stem cell of primates has been possible using traditional titer retrovirus cell lines.

This same report described the generation of a retrovirus packaging cell line of exceptionally high titer to overcome the low level gene transfer into primate hematopoietic stem cells. This cell line was produced by coculturing two different packaging cell lines of different host ranges (a repetitive cross infection method). The packaging cell line was initially reported to have a titer of $10^{10} \mathrm{CFU} / \mathrm{ml}(1000$-fold higher than any previous report), however, another group reported a titer of $4 \cdot 10^{7} \mathrm{CFU} / \mathrm{ml}$ for the cell line [66]. In addition, this cell line is contaminated with at least $10^{3}$ titer replication competent retrovirus. This packaging cell line also continuously secretes interleukii 3 and interleukin 6 into the tissue culture media.

The first experiments performed with the high titer line demonstrated that it could efficiently transduce the hematopoietic stem cells of mice [65]. Ten mice were transplanted with bone marrow transduced with the high titer line and all were positive for provirus at 3 months after bone inarrow transplantation. The trans. planted mice demonstrated a reasonable amount of provirus in their hematopoietic tissue, estimated to be between $0,1=0,3$ copies per cell. Having this initial encouraging results, three monkeys were transplanted with bone marrow transduced with the high titer line packaging cell line. All three survived the transplant. Reniarkably, ail were positive for provirus derived sequences (by polymerase chain reaction). One animal was killed 99 days after bone marrow transplantation, and provirus was present in about 190 of hematopoietic cells, based on semiquantitative polymerase chain reaction. Thus, it seemed possibic that with high enough titer virus that the hematopoietic stem cell of primates (and perhaps humans) could be transduced, albeit at low levels.

In 1991 an update was provided on both the gene transfer efficiency and the safety of this high titer, helper virus infected cell line when used to transduce primate bone marrow [95]. Additional rhesus monkeys were transplanted with bone marrow transduced with the same high titer producer cell line in the presence of autologous bone marrow stromal cells. Prior to retrovirus transduction, the bone marrow was affinity purified on a CD34 column to enrich for hematopoietic stem cells. Proviral sequences were detectable in up to $10 \%$ of the peripheral blood $\mathrm{T}$ cells, and in one of the animals the provirus sequences could be detected by
Southern blot. Unfortunately, 3 of the 6 transplanted animals developed thymic lymphoma. The histology was that of a large cell immunoblastic lymphoma, reminiscent of the tumors caused by wild type Moloney virus in mice. The monkeys were also shown to be persistently viremic with Moloney virus. Southern blot analysis of the thymic tumors demonstrated multiple copies of the provirus in the tissue, implicating the replication of infectious retrovirus within the animals. The thymus also was positive for retrovirus derived envelope protein. This essentially recapitulated Moloney disease in non-human primates through exposure to a large amount of virus in a very immune suppressed animal.

While this was a major break thorough in terms of the level of gene transfer into the primate hematopoietic cell, it also demonstrates the potential for significant toxicity of wild type murine retroviruses in primates. It reinforces the need to carefully assay retroviral stocks used for clinical gene therapy protocols for the presence of replication competent retrovirus. It also holds hope that with high enough titer replication virus free stocks of retrovirus that adequate levels of gene transfer into the hematopoietic stem cell of primates and eventually humans can be achieved.

\section{Current clinical trials of human gene therapy}

The first trials of introducing a therapeutic gene were attempted by an American investigator who performed clinical trials on two patients overseas. These experiments were never approved by the United States regulatory agencies. The results were reported in 1985 [96]. In these experiments, $10^{8}$ nucleated marrow cells were transfected with a plasmid vector that contained herpes virus thymidine kinase gene and a human $\beta$ globin gene. The cells and transfection vector were incubated in vitro, and then infused into two patients who had received 0.3 Gray external beam irradiation delivered to the femur. The investigator was unable to detect vector specific sequences before the transplant. Between 1-2 weeks after the transplant, less than one copy of the transfected sequences were detected by Southern blot. An occasional higher molecular weight species was observed, perhaps indicating integration of the sequences. After 10 weeks, there was no evidence of the higher molecular weight species of transfected DNA. The transfected DNA became undetectable after three months in one patient and nine months in another patient. The change in hemoglobin levels was not reported for either patient. No toxicity was observed in either patient from the procedure. This experiment illustrated the difficulty in obtaining long term retention of the genetic material in the bone marrow of humans when there is no selective pressure for the maintenance of the introduced sequences. 
The first fully approved human trial using genetically altered $T$ lymphocytes was reported in 1990 [2]. The investigators used the retrovirus LNL6, wish a best titer $2 \cdot 10^{6} \mathrm{CFU} / \mathrm{ml}$, to mark tumor infiltrating lymphocytes (TIL) from 5 patients with inetastatic meianoma. The TIL were exposed to retrovirus containing tissue culture supernatants for $2 \mathrm{~h}$ or 2 consecutive days. This resulted in the transduction of between $1-11 \%$ of the cells. Drug resistant lymp socytes all showed presence of unrearranged provirus. Interestingly, the transduced cells did show some changes in cell surface phenotype, although a consister t pattern of change was not observed. Transduced cells from 5 of 6 of the initially reported patients showed reduction in killing of K562 and Daudi cells, but 4 of the 6 patients transduced cells demonstrated an increase in autolo. gous tumor cell killing. After infusion of genetically marked TIL, the investigators were able to detect the presence of provirus in peripheral blood and occasion. ally in tumor biopsy speciniens. There was no additional toxicity of the genetically modified TIL above toxicity observed with interleukin 2 and unmodified TIL.

The TIL marking trial demonstrated several important points. First, genetically modified cells could be given to patients with no more toxicity that of the unmodified, ex vivo cultured cells. Second, retroviruses could be generated safely and repetitively in large enough quantities for human gene therapy. Third, provirus could be used to genetically mark cells in humans, which had already been performed in animals. This initial safety study paved the way for the first fully approved human gene therapy trial, now underway at the NIH.

As of July, 1992, two patients have been treated with genetically modified lymphocytes in an attempt to ameliorate ADA deficiency [1]. The first patient was treated in September, 1990. In this clinical protocol, the retroviral vector LASN (essentially LNL6 with the addition of an ADA CDNA) was used to transduce the peripheral blood lymphocytes of a patient. The lymphocytes were ex vivo expanded in the presence of an antibody to T3 (OKT3) and interleukin 2. The cells were then exposed to the retrovirus, and infused into the patient. The first patient, a $4 \mathrm{yr}$ old girl, has received a total of 8 dnses of genetically modified $T$ cells, obtaining up to $25 \%$ of normal peripheral blood ADA levels (as compared to less then $1 \%$ pretreatment). A second patient, an $11 \mathrm{yr}$ old girl, has received 11 infusions of genetically modified $\mathrm{T}$ cells. The results have not yet been reported for this patient.

The genetically modified $T$ cells in one of the patients have a half-life of about $\mathbf{9 0}$ days, approximately 3-4 times that of the ex vivo expanded, unmodified $T$ cells. These patients have maintained their current regimen of ADA replacement with polyethylene glycol modified adenosine deaminase. In addition, the investigators have been able to demonstrate reconstitution of isohemaglutinins, diphtheria, and tetnus antibodies. These initial very promising results have lead to a proposal to genetically modify the hematopoietic stem cell of these two patients.

The Recombinant DNA advisory committee of the NIH has recently approved a protocol to genetically modify the peripheral blood stem cells of these same two patients, and the protocol is awaiting final FDA approval. The proposed trial is to harvest peripheral blood stem cells, enrich for CD34 positive cells, expose the CD34 positive cells to a recombinant retrovirus encoding for adenosine deaminase in the presence of growth factors (interleukin 3, interleukin 6, and stem cell factor), and reinfuse the genetically modified cells back into the patients. This trial stands a reasonable chance of success because even at lower gene transfer levels obtainable into the hernatopoietic stem cell of primates, there is a selective pressure for the geneticilly modified cells in patients with ADA deficiency. In addition, the patients need not be subjected to pretransplant transplant myeloablation, and so the risk of the procedure is almost identical to that of infusing transduced $T$ cells. This should provide an exciting starting ground for many human trials to come in the years ahead.

\section{Concluding remarks}

Hematopoietic stem cell gene therapy offers much promise for the cure of diseases. In adenosine deaminase deficiency, clinical trials of human hematopoietic stem cell gene transfer are about to commence. The advent of clinical trials represent the combined hard work of a number of investigators. Gene therapy trials of this discase have a relatively high chance of success and pose little risk to the patient because of the wide range of normal expression of adenosine deaminase and the ability to cure patients without performing bone marrow transplantation conditioning. While likely to be successful, the total clinical impact in health care may be small because of the relative rarity of adenosine deaminase deficiency.

In contrast, the treatment of the hemoglobinopathies (such as sickle cell disease and severe thalessemia) with hematopoietic stem cell gene therapy still appears to be years away. This relates to the problems of achieving high enough levels of the recombinant protein expressed in the majority oi erythrocytes to provide amelioration of the disease. In addition, patients with these diseases are at greatly increased risk of increased mortality with bone marrow transplantation because of their iron overload status and subsequent end organ damage. Furthermore, they must be conditioned with chemotherapy to engraft the multipotent hemato- 
poietic stem cell which gives rise to erythrocytes. Thus, there is a great deal of investigation to be performed to bring to fruition clinical trials in the hemoglobinopathies.

These two conditions provide the range of the clinical problems encountered with genetically modifying the hematopoietic stem cell. Adenosine deaminase deficient patients have a debilitating and lethal disease, and provide a selective advantage to genetically modified hematopoietic stem cells. Additionally, a wide range of expression of the transgene should provide a therapeutic benefit. On the other hand, the hemoglobinopathies require a high level of expression of protein at a very limited point in erythroid development. The patients with the hemoglobinopathies must be subjected to a more risky transplant because there is no selective advantage for normal cell, and they are at greater risk of transplant because of their underlying disease. Thus, before a clinienl trial could commence, adequate levels of gene transfer and adequate levels of transgene expression would need to be demonstrated. For the hemoglobinopathies, neither of these conditions have been met, and this poses a challenge for investigators of hematopoietic stem cell gene therapy to overcome.

\section{References}

I Anderson, W.F. (1992) Science 256, 808-813,

2 Rosenberg, S.A. Aebersold, P., Cornetta, K., Kasid, A., Morgan, R.A. Moen. R., Karson, E., Lotze, M.T., Yang, J.C., Topalian, S.L. Merino, M.J., Culver, K., Miller, A.D., Blaese, R.M. and Anderson, W.F. (1990) New Eng, J, Med, 232, 57(1)-570-578.

3 Murpay, J.E. (1992) Science 256, 1411-1416.

4 Hall, S.S, (1992) Science 256, 1532.

5 Hershfield, M.S. Buckley, R.H., Greenber, N.L., Molton, A.L., Schiff, R, Hatem, C. Kurtzberg. J., Markert, M.L. Kobayashi. R.H、 Kobayash, A.L. and Abuchowski, A, (1987) New Eng, J. Med, $316,589=596$.

6 MeLachlin, J.R. Eglitis, M.A. Ueda, K. Kantoff, P.W. Anderson. W.F. and Gottesman. M.M. (1990) J, Natl. Cancer Inst. 82. $13601-1363$

7 Culver, K.W. Ram, Z、Wallbridge, S. Ishiii, H. Oldfield, E.H. and Blaewe. R.M. (1992) Science 256, 1550-1552.

8 Nienhuis, A.W., McDonagh, K.T, and Bodine, D.M. (1991) Cancer $67,10,2700-2704$.

9 Kohn. D.B. Anderson. W.F, and Blaese, R.M. (1989) Can. Invest, $7,179=192$.

1) Blacse. R.M. (1991) Clin. Immun. Immunopathol, 61, S47-555.

11 Beutler, E. and Sorge. J. (199(1) Exp. Hem, 18, 857-860.

12 Berenson. R.J. Andrews, R.G., Bensinger. W.I., Kalamasa, D.F.. Knilter. G. Buckner. C.D. and Berstein. I.D. (1988) J. Clin. Invest, $81,951=955$,

13 Berensom, R.J., Bensinger, W.I., Hill, R.S., Andrews, R.G., Garcia-Lopez, J. Lalamasz. D.F. Still, B.J., Spitzer, G. Buckner. C.D. Bernstein. I.S. and Thomas, E.D. (1991) Blood 77, 17171722.

14 Nabel, E.G. Plautz, G. and Nabel, G.J. (1990) Science 249. $1285-1288$

15 Accadi, G. Dickson, G., Love, D.R., Jani. A., Walsh, F.S.,
Gurusinghe, A., Wolff, J. and Davies, K.E. (1991) Nature 352, 815-818.

16 Hatzoglou, M., Lamers, W., Bosch, F., Wynchaw-Boris, A., Clapp, D.W. and Hanson. R.W. (1990) J. Biol. Chem. 265, 17285-17293.

17 Quine, W.E. (1896) J. Am. Med. Assoc. 26, 1012-1013.

18 Osgood, E.E., Riddle, M.C. and Matthews, T.J. (1939) Ann. Intern. Med. 13, 357.

19 Morrison, M. and Samwick, A.A. (1940) JAMA 115, $1708-1711$.

20 Santos, G.W. (1983) Clin. Haem. 12, 639.

21 Furd, C., Hamerton, J.L., Barnes, D.W.H. and Loutit, J.F. (1956) Nature 177, 452-454.

22 Thomas, E.D., Lochte, H.L., Lu, W.C. and Ferrebee, J.W. (1957) New Engl. J. Med. 257, 491-49\%.

23 Thomas, E.D., Storb, R., Clift, R.A., Fefer, A., Johnson, F.L., Neiman P.E., Lerner, K.G., Gucksberg, H. and Buckner, C.D. (1975) New Engl. J. Med. 292, 832-843, 895-902.

24 Gutt, R.A., Meuwissen, H.J.. Alken, H.D., Hong, R. and Good, R.A. (1968) Lancet ii, 1366-1369.

25 Bach, F.H., Albertini, R.J., Joo, P., Anderson, J.L. and Bortin, M.M. (1968) Lancet ii, 1364-1366.

26 Hobbs, J.R. (1990) J. Inher, Met. Dis, 13, $572=59 \%$.

27 Ichioks, T., Kishimoto, Y., Brennan, S., Santos, G, and Yenger, A.M. (1987) Proc. Natl. Acad. Sci. USA 84, 4259)-4263.

28 Hoogerbrugge, P.M., Suzuki, K., Suzuki, K., Poorthuis, B.J.H.M., Kobayashi. T., Wagemaker, G. and Van Bekkum, D.W. (1988) Science 239, 1035-1038.

29 O'Reilly, R.J. (1983) Blood 62, 941-964.

30 Pedrazzini, A., Freedman, A.S. and Nadler, L.M. (1989) Biochim. Biophys. Acta 989, 11-24.

31 Cheson, B.D., Lacerna, L., Leyland-Jone, B., Sarosy, G. and Wittes, R.E. (1989) Ann. Intern. Med. 110, 51-65.

32 Weiss, R., Teich, N., Varmus, H. and Coffï, J. (1984) RNA Tumor Viruses, Cold Spring Harbor Laboratory, Cold Spring Harbor.

33 Coffin, J.M. (1990) in Virology (Fields. B.N., Knipe. D.M. et al., eds.), pp. 1437-1500, Raven Press, New York.

34 Rous, P. (1911) JAMA 56, 198-202.

35 Gross, L. (1951) Proc. Soc. Exp. Biol. Med. 78, 342-348.

36 Moloney, J.B. (1960) J. Natl. Cancer Inst. 24, 933-947.

37 DesGroseillers, L. and Jolicoeur, P. (1984) J. Virol. 52, 448-456.

38 DesGroseillers, L. and Jolicoeur, P. (1983) J. Virol. 48, 685-696.

39 Shinnick. T.M., Lerner, R.A. and Sutcliffe, J.G, (1981) Nature 243. 543-548.

40 Miller, A.D, and Verma. I.M. (1984) J. Virol. 49, 214-222.

41 Miller, A.D. and Buttimore, C. (1986) Mol. Cell. Biol. 6, 28952902 .

42 Leis, J., Baltimore, D., Bishop. J.M., Coffin, J., Fleissner, E., Goff. S.P., Oroszlan, S., Fobinson. H., Skalka, A.M., Temin, H.M. and Vogt, V. (1988) J. Virol. 62, 1808-1809.

43 Shimotohno, K. and Temin, H.M. (1981) Cell 26, 67-77.

44 Tabin, C.J., Hoffmann, J.W., Goff, S.P. and Weinberg, R.A. (1982) Mol. Cell. Biol. 2, 42-436.

45 Miller, A.D., Jolly, D.J., Friedmann, T. and Verma, I.M. (198.3) Proc. Natl. Acad. Sci. USA 80, 4709-4713.

46 Miller, A.D., Eckner, R.J.. Jolly. D.J., Friedmann, T. and Verma, I.M. (1984) Science 225, 630-632.

47 Watanabe, S. and Temin, H.M. (1982) Proc. Natl. Acad. Sci. USA 79. $5986-5990$.

48 Mann. R.. Mulligan, R.C. and Baltimore, D. (1983) Cell 33, 153-159.

49 Cone, R.D. and Mulligan, R.C. (1984) Proc. Natl. Acad. Sci. USA 81. 6349-6353.

50 Sorge. J., Wright, D., Erdman, V.D. and Cutting, A.E. (1984) Mol. Cell. Biol. 4. 1730-1737.

51 Miller, A.D., Law, M.F. and Verma, I.M. (1985) Mol. Cell. Biol. 5, 431-437. 
52 Danos, O. and Mulligan, R.C. (1988) Proc. Natl. Acad. Sci. USA $85,6460-6464$.

53 Markowitz, D., Goff, S. and Bank, A. (1988) J. Virol. 62, 11201124.

54 Markowitz, D., Hesdorffer, C., Ward, M., Goff, S. and Bank, A. (1989) Ann. N.Y. Acad. Sci. 407-411.

55 Points to consider in human somatic cell therapy and gene therapy (1991) Human Gene Ther. 2, 2.51-256.

56 Epstein. S.L. (1991) Human (iene Ther. 2, 243-249.

57 Cepko, C., Roberts, B.E. and Mulligan, R.C. (1984) Cell 37, 1053-1062.

58 Armentano, D., Yu, S.F., Kantoff, T., Von Ruden, T., Anderson, W.F. and Gilboa, E. (1987) J. Virol. 61, 1647-1650.

59 Bender, M.A., Palmer, T.D., Gelinas, R.E. and Miller, A.D. (1987) J. Virol. 61, 1639-1646.

60 Adam, M.A. and Miller, A.D. (1988) J. Virol. 62, 3802-3806.

61 Miller, A.D. and Rosman, G.J. (1989) BioTechniques 7, 980-990.

62 Guild, B.C., Finer, M.C. Housman, D.E. and Mulligan, R.C. (1988) J. Virol. 62, 379,5-3801.

6.3 Wilson, J.M., Johnston, D.E., Jefferson, D.M. and Mulligan, R.C. (1988) Proc. Nutl. Acad. Sci. USA 85, 4421-4425.

64 Adam. M.A., Ramesh, N., Miller, A.D. and Osborne, W.R.A. (1901) J. Virol. 6.5, 4985-4090.

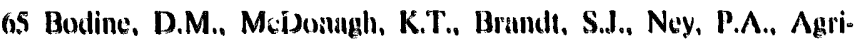
cola, B., Byrne, E. and Nienhuis, A.W. (1990)) Proc. Natl. Acad. Sci. USA 87, 3738-374\%.

66 Lynch, C.M. and Milier, A.D. (1991) J. Virol, 65, 3887-3890).

67 Dougherty, J.P., Wisniewski, R., Yang, S., Rhode, B.W. and Temin, H.M. (1989) J. Virol. 63, 3209-3212.

68 Cline, M.J., Stang, H., Mercola, K, Morse, L., Ruprecht, R., Browne, J. and Salser, W. (1980) Nature 284, 422-425.

69 Mercola, K.E., Stang, H.D., Bowne, J., Salser, W. and Cline, M.J. (1980) Science 208, 1033-1035.

70 Williams, D.A., Lemischka, I.R., Nathan, D.G. and Mulligan, R.C. (1984) Nature 310, 470-480,

71 Keller, G., Paige, C., Gilboa, E. and Wagner, E.F. (1985) Nature 318, 149-154.

72 Van Beusechem, V.W., Kukler, A., Einerhand, M.P.W., Bakx, T.A., Vander Eb, A.J., Van Bekkum, D.W. and Balerio, D. (1990) J. Exp. Med. 172, 729-736.

73 Belmont, J.W., MacGregor, G.R., Wager-Smith, K., Fletcher, F., Moore, K.A., Hawkins, D., Villalon, D., Chang, S.M.W. and Caskey, C.T. (1988) Mol. Cell. Biol. 5116-5125.

74 Dzierzak, E.A., Papayannopoulou, T. and Mulligan, R.C. (1988) Nature 331, 35-41.

75 Bender, M.A., Gelinas, R.E. and Miller, A.D. (1989) Mol. Cell. Biol. 9, 1426-1434.

76 Wilson, J.M., Danos, O., Grossman, M., Raulet, D.H. and Mullisan, R.C. (1990) Proc. Natl. Acad. Sci. USA 87, 439-443.
77 Weinthal, J., Nolta, J.A., Yu, X.J., Lilley, J. and Kohn, D.B. (1991) Bone Mar. Trans. 8, 403-412.

78 Krauss, J.C., Mayo-Bond, L., Rogers, C., Weber, L., Todd III, R.F. and Wilson, J.M. (1991) J. Clin. Invest. 88, 1412-1417.

79 Krauss, J.C., Mayo-Bond, L., Weber, K.L., Wiison, J.M. and Todd Ill, R.F. (1992) Clin. Res. 40, 283A.

80) Spangrude, G.J., Heimfeld, S. and Weissman, I.L. (1988) Science $241,58-62$.

81 Smith, L.J., Weissman, 1.U.L. and Heimfield, S. (1991) Proc. Natl. Acad. Sci. USA 88, 2788-2792.

82 Spangrude, G.J., Smith, L., Uchida, J.N., Ikuta, K., Heimfeld. S., Friedman, J. and Weissman, l.L. (1991) Blood 78, 1395-1412.

83 Szilvassy, S.J., Fraser, C.C., Eaves, C.J., Lansdorp, P.M., Eaves, A.C. and Humphries, R.K. (1989) Proc. Natl. Acad. Sci. USA 8798-8802.

84 Szilvassy, S.J., Lansdorp, P.M., Humphries, R.K., Eaves, A.C. and Eaves, C.J. (1989) Blood 74, 930-939.

85 Storb, R., Rudolph, R.H., Kolb, H.J., Graham, T.C., Mickelson, E., Erickson, V., Lerner, K.G., Kolb, H. and Thomas, E.D. (1973) Transplantation 15, 92-100.

80 Weiden, P.L., Storb, R., Graham, T.C. and Schroder, M.L. (1976) Br. J. Haem. 33, 357.

87 Weiden, P.L., Hackman, R.C., Deeg, H.J., Graham, T.C., Thomas, E.D. and Stor'b, R. (1981) Blood 57, 66.

88 Carter, R.F., Abrams-Ogg ACG, Dick, J.E., Kruth, S.A., Valli, V.E., Kamel-Reid, S. and Dube, I.D. (1992) Blood, 79, 356-364.

89 Stend, R.B., Kwok, W.W., Storb, R. and Miller, A.D. (1988) Blood 71, 742-747.

90 Kwok, W.W., Scheuning, F., Stead, R.B. and Miller, A.D. (1986) Proc. Natl. Acad. Sci. USA 83, 4552-4555.

91 Lothrop, C.D., Al-Lebban, Z.S., Niemeyer, G.P., Jones, J.B., Peterson MG, Smith, J.R., Baker, H.J., Morgan, R.A., Eglitis, M.A. and Anderson, W.F. (1991) Blood 78, 238-245.

92 Kantoff, P.W., Gillio, A.P., McLachlin, J.R., Bordignon, C., Eglitis MA, Kernan, N.A., Moen, R.C., Kohn, D.B., Yu, S.F., Karson, E., Karlsson, S., Zweibel, J.A., Gilboa, E., Blaese, R.M., Nienhuis, A., O'Reilly, R.J. and Anderson, W.F. (1987) J. Exp. Med. 166, 219-234.

93 Cornetta, K., Weider, R. and Anderson, W.F. (1989) Prog. Nucleic Acid Res. Mol. Biol, 36, 311.

94 Kantoff, P.W., Gillio, A.P., McLachlin, J.R., Flake, A.W., Eglitis, M.A., Kernan, N.A., Moen, R.C., Karlsson, S., Kolnn, D.B., Karson, E., Zweibel, J.A., Bordignon, C., Hutton, J.J., Harrison, M.R., Blaese, R.M., Nienhuis, A., Gilboa, E., Zanjani, E.D., O'Reilly, R.J. and Anderson, W.F. (1986) Am. Phys. 99, 92-102.

95 Donahue, R.E., Kessler, S.W., Bodine, D.M., Agricola, B.A., Byrne, E.R., Metzger, M.E., McDonagh, K.T., Bacher, J.D., Zsebo, K.M. and Nienhuis, A.W. (1!91) Blood 78, Suppl. 1, 79a. 96 Cline, M.J. (1985) Pharm. Ther. 29, 69-92. 